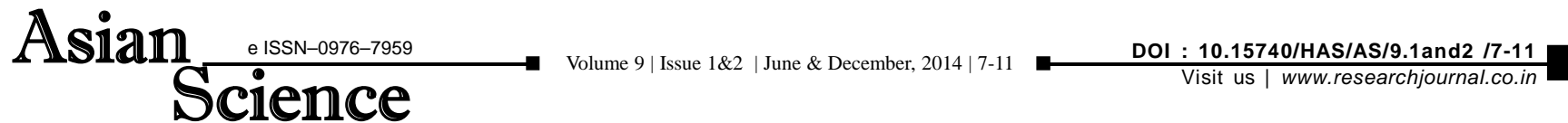

RESEARCH PAPER

\section{Ergonomic evaluation of hill farm women in paddy transplanting activity}

\author{
NEENA VYAS*, LAXMI DEVI AND JATINDER KISHTWARIA \\ Department of Family Resource Management, College of Home Science, C.S.K. Himachal Pradesh Krishi \\ Vishvavidyalaya, PALAMPUR (H.P.) INDIA
}

\begin{abstract}
In almost all rice growing areas of Himachal Pradesh, women are responsible for sowing, transplanting, weeding etc. Majority of farm women are involved in household, agricultural and allied activities. Therefore, the main problems of rural farm women are long working hours of heavy work, low productivity and limited access to new technology. The transplanting activity performed by women has a strong bearing on their health. Hence, the present study was formulated with the objective to determine the ergonomic cost of paddy transplanting in existing working situations and to identify suitable technology to reduce the drudgery of work. Ergonomics evaluation of respondents were carried out in relation to physiological stresses viz., Heart rate, Energy expenditure, Grip strength and physical fatigue. Thirty (30) volunteer respondents selected for experimental work under present investigation. The readings were recorded while the selected respondents performed the paddy transplanting activity on existing working conditions for 30 minutes each. Results revealed that there was significant per cent increase in physiological stresses mainly in heart rate and energy expenditure before and during transplanting activity while working with traditional methods/tools. Campaigns were conducted to generate awareness on the use of manual transplanter, as it reduces time and energy of the respondents. Thus, after imparting training on improved technology that is manual transplanter majority of the selected respondents were willing to purchase the same. It can be concluded that the finding of the study can be useful to farm ladies to reduce their drudgery by using improved technologies.
\end{abstract}

Key Words : Transplanting, Drudgery, Physiological stresses, Energy expenditure

View point paper : Vyas, Neena, Devi, Laxmi and Kishtwaria, Jatinder (2014). Ergonomic evaluation of hill farm women in paddy transplanting activity. Asian Sci., 9(1\&2): 7-11.

\footnotetext{
* Author for correspondence

Neena Vyas, Department of Agricultural Engineering, College of Agriculture, C.S.K. Himachal Pradesh Krishi Vishvavidyalaya, PALAMPUR (H.P.) INDIA
} 